Public Health of Indonesia

\title{
THE IMPLEMENTATION OF NEW NORMAL POLICIES DURING THE COVID-19 PANDEMIC IN KENDARI CITY, SOUTHEAST SULAWESI, INDONESIA: KNOWLEDGE, ATTITUDES AND PRACTICE
}

\author{
Juminten Saimin ${ }^{1}$, Nur Indah Purnamasari ${ }^{1}$, Hartati ${ }^{2}$ \\ ${ }^{1}$ Department of Obstetrics and Gynecology, Faculty of Medicine, Halu Oleo University, Kendari, Indonesia \\ ${ }^{2}$ Department of Biomedicine, Faculty of Medicine, Halu Oleo University, Kendari, Indonesia
}

Received: 23 September 2020 | Accepted: 24 September 2020

DOI: https://dx.doi.org/10.36685/phi.v6i3.346

\section{Correspondence:}

Dr.dr. Juminten Saimin, SpOG (K)

Department of Obstetrics and Gynecology, Faculty of Medicine, Halu Oleo University

Jl. Syaikh Muhammad Al-Khidhir, Kambu, Kec. Kambu, Kota Kendari, Sulawesi Tenggara 93561, Indonesia

Email: inten azis@yahoo.com

Mobile: 085241697071

Copyright: (C) 2020 the author(s). This is an open-access article distributed under the terms of the Creative Commons Attribution Non-Commercial License, which permits unrestricted non-commercial use, distribution, and reproduction in any medium, provided the original work is properly cited.

\footnotetext{
ABSTRACT

Background: The new normal policy during the COVID-19 pandemic requires public participation. Efforts to suppress the number of cases require knowledge, attitudes and behavior towards health protocols to prevent COVID-19.

Objective: This study aimed to assess knowledge, attitudes and practice towards the prevention of COVID-19.

Method: This was a descriptive study which included 409 respondents in Kendari City Indonesia conducted in July-August 2020. Data were collected through online questionnaires with google forms.

Results: Most of the respondents knew the causes of COVID-19 (85.1\%), mode of transmission (65.0\%), prevention with masks $(96.4 \%)$, washing hands $(90.5 \%)$, social distancing $(98.1 \%)$, and cough etiquette $(80.4 \%)$. The attitudes towards public opinions varied. The behaviors towards the prevention of COVID-19 were reading (90.2\%), protecting themselves $(94.4 \%)$, positive thinking $(96.1 \%)$, doing activities at home (87.3\%) and social distancing $(93.2 \%)$. The behavior to avoid fake news was to ensure the news sources (72.6\%), accessed official news $(85.5 \%)$ and accessed many sources $(73.8 \%)$.

Conclusions: The community of Kendari City has adequate knowledge, attitudes and practice towards prevention of COVID19. This is a potential asset to implementing the new normal policy during the COVID-19 pandemic.

Keywords: attitudes, COVID-19, knowledge, new normal, practice
}

\section{BACKGROUND}

World Health Organization (WHO) has declared the Coronavirus disease 2019 (COVID-19) pandemic at the beginning of 2020 (World Health Organization, 2020a). Coronavirus is a new strain of severe acute respiratory coronavirus- 2 which is rapidly spreading around the world, including Indonesia. Several policies have taken to deal with the pandemic, such as health protocols and large-scale social distancing policy (Kementerian Kesehatan Republik Indonesia, 2020).

The COVID-19 pandemic has affected community lives. In June 2020 the Government of Indonesia established a new normal policy or new habits in dealing with the COVID-19 pandemic. This policy was carried out to prevent the adverse effects of the pandemic. The new habit order requires that people continue to carry 
out normal social activities but by implementing health protocols to avoid the spread of COVID19 (Pratama, 2020). Wearing masks, washing hands, applying cough etiquette, avoiding contact with sufferers and maintaining distance are recommended health protocols (World Health Organization, 2020b).

Effort to suppress the number of cases requires the community participation to implementing the health protocols that are regulated in the guidelines of new normal policy. Community participation requires positive knowledge, attitudes, and behavior. The community has a major contribution in breaking the chain of transmission. A study in China found that people with adequate knowledge of COVID-19 have positive behavior in dealing with the pandemic (Zhong et al., 2020).

The COVID-19 case in Kendari City is the highest in Southeast Sulawesi, Indonesia. Kendari City as the provincial capital is the entrance and exit point for Southeast Sulawesi. Therefore, we want to assess the knowledge, attitudes and behavior of the community in implementing new normal policies during the COVID-19 pandemic in Kendari City, Indonesia.

\section{METHODS}

\section{Study Design}

This was a descriptive study conducted in Kendari City on July-August 2020. There were 409 respondents.

\section{Data Collection}

Data were collected using questionnaires and given online with google form through the WhatsApp and social media group. The questionnaire contains research objectives and a willingness to be a respondent. If the respondent is willing, he/she will start on the next page which contains the research question. The first question concerns the sociodemographic. The next question concerns knowledge about the transmission and prevention of COVID-19, attitudes towards opinions about COVID-19, behaviors to protect themselves against COVID-
19 transmission and avoid fake news about COVID-19.

\section{Data Analysis}

The data obtained were tabulated and presented in table and narrative form. Descriptive statistics were used.

\section{Ethical Consideration}

This study was ethically approved by Health Research Ethics Commission, Faculty of Medicine, Halu Oleo University, Kendari, Indonesia.

\section{RESULTS}

There were 409 respondents, consisting of men (43.5\%) and women (56.5\%). Almost half of the respondents were 21-30 years old (41.8\%), with middle $(42.5 \%)$ and high education levels (44.0\%), and had varied occupations (See Table 1).

Table 1 Characteristics of Respondents

\begin{tabular}{llcc}
\hline \multicolumn{2}{c}{ Characteristics } & n & \% \\
\hline Sex & Male & 178 & 43.5 \\
Age (years old) & Female & 231 & 56.5 \\
& $<20$ & 149 & 36.4 \\
& $21-30$ & 171 & 41.8 \\
Education levels & $>30$ & 89 & 22.8 \\
& Low & 55 & 13.5 \\
& Middle & 174 & 42.5 \\
Occupation & High & 180 & 44.0 \\
& Student & 102 & 24.9 \\
& Student of & & 27.4 \\
& college & 112 & \\
& Employee & 122 & 29.8 \\
& Self-employed & 73 & 17.9 \\
\hline
\end{tabular}

Most respondents answered that they knew the causes of COVID-19 (85.1\%) and the transmission of COVID-19 (65.0\%). However, there were respondents who answered "hesitant" about causes $(14.2 \%)$ and transmission $(26.2 \%)$ of COVID-19. Almost all respondents answered "yes" that they knew about prevention by using masks (96.4\%), washing hands (90.5\%), social distancing $(98.1 \%)$, and cough etiquette $(80.4 \%)$ (See Table 2). 
Table 2 Knowledge about COVID-19

\begin{tabular}{|c|c|c|c|c|c|c|}
\hline \multirow{2}{*}{ Knowledge } & \multicolumn{2}{|c|}{ No } & \multicolumn{2}{|c|}{ Hesitant } & \multicolumn{2}{|c|}{ Yes } \\
\hline & $\mathbf{n}$ & $\%$ & $\mathbf{n}$ & $\%$ & $\mathbf{n}$ & $\%$ \\
\hline \multicolumn{7}{|l|}{ Knowledge regarding COVID-19 transmission } \\
\hline Causes of COVID-19 & 3 & 0.7 & 58 & 14.2 & 348 & 85.1 \\
\hline Transmission through droplet or closed contact with patients & 36 & 8.8 & 107 & 26.2 & 266 & 65.0 \\
\hline \multicolumn{7}{|l|}{ Knowledge regarding the prevention of COVID-19 } \\
\hline Using face masks & 5 & 1.2 & 10 & 2.4 & 394 & 96.4 \\
\hline Washing hand regularly & 8 & 1.9 & 31 & 7.6 & 370 & 90.5 \\
\hline Social distancing & 3 & 0.7 & 5 & 1.2 & 401 & 98.1 \\
\hline Cough etiquette & 15 & 3.7 & 65 & 15.9 & 329 & 80.4 \\
\hline
\end{tabular}

Attitudes of community towards opinions about COVID-19 were varied. The attitude towards the opinion that someone who buys products from China can contract COVID-19 was almost the same, both disagree (29.6\%), hesitant $(36.9 \%)$, and agree (33.5\%). Response to the opinion on disinfectant spraying was almost the same between agreeing (37.4\%) and hesitant $(38.4 \%)$. Most of the respondents disagreed (44.5\%) and doubted (40.3\%) the opinion that eucalyptus oil, garlic and sesame can prevent transmission of COVID-19. More than half of respondents answered "agree" $(58.9 \%)$ that COVID-19 was the same as the common cold. Half of respondents answered doubt that COVID-19 can be treated with antibiotics (51.3\%). Majority respondents answered "hesitant" that the corona virus will die at high temperatures (73.8\%) (See Table 3).

Table 3 Attitudes towards Public Opinion Regarding COVID-19

\begin{tabular}{|c|c|c|c|c|c|c|}
\hline \multirow{2}{*}{ Public opinions } & \multicolumn{2}{|c|}{ Disagree } & \multicolumn{2}{|c|}{ Hesitant } & \multicolumn{2}{|c|}{ Agree } \\
\hline & $\mathbf{n}$ & $\%$ & $\mathbf{n}$ & $\%$ & $\mathbf{n}$ & $\%$ \\
\hline Buying products from China causes infected COVID-19 & 121 & 29.6 & 151 & 36.9 & 137 & 33.5 \\
\hline Spraying disinfectant on the body can prevent COVID-19 & 99 & 24.2 & 157 & 38.4 & 153 & 37.4 \\
\hline $\begin{array}{l}\text { Eucalyptus oil, garlic and sesame can prevent COVID-19 } \\
\text { infection }\end{array}$ & 180 & 44.5 & 163 & 40.3 & 62 & 15.2 \\
\hline COVID-19 is the same as the common cold & 241 & 58.9 & 109 & 26.6 & 59 & 14.5 \\
\hline COVID-19 can be treated with antibiotics & 103 & 25.2 & 210 & 51.3 & 96 & 23.5 \\
\hline Coronavirus will die in high temperature & 52 & 12.7 & 302 & 73.8 & 55 & 13.5 \\
\hline
\end{tabular}

Table 4 Practice About Self-Protection Efforts in Preventing COVID-19

\begin{tabular}{|c|c|c|c|c|c|c|}
\hline \multirow{2}{*}{ Practice } & \multicolumn{2}{|c|}{ No } & \multicolumn{2}{|c|}{ Sometimes } & \multicolumn{2}{|c|}{ Yes } \\
\hline & $\mathbf{n}$ & $\%$ & n & $\%$ & $\mathbf{n}$ & $\%$ \\
\hline \multicolumn{7}{|l|}{$\begin{array}{l}\text { Efforts to self-protection against transmission of COVID- } \\
19\end{array}$} \\
\hline $\begin{array}{l}\text { Reading news about COVID-19, mode of transmission and } \\
\text { prevention }\end{array}$ & 5 & 1.2 & 35 & 8.6 & 369 & 90.2 \\
\hline Perform self-protection protocols & 3 & 0.7 & 20 & 4.9 & 386 & 94.4 \\
\hline Positive thinking & 0 & 0 & 16 & 3.9 & 393 & 96.1 \\
\hline Doing activities at home to prevent transmission of COVID-19 & 12 & 2.9 & 40 & 9.8 & 357 & 87.3 \\
\hline Try to limit contact and social distancing & 7 & 1.7 & 21 & 5.1 & 381 & 93.2 \\
\hline \multicolumn{7}{|l|}{ Efforts to self-protection against fake news of COVID-19 } \\
\hline Stop reading the news from social media & 325 & 79.4 & 62 & 15.2 & 22 & 5.4 \\
\hline Just accept the news got from social media & 264 & 64.5 & 58 & 14.2 & 87 & 21.3 \\
\hline Ask to the sender for the original source & 83 & 20.3 & 29 & 7.1 & 297 & 72.6 \\
\hline $\begin{array}{l}\text { Consider news only from official government and WHO } \\
\text { sources }\end{array}$ & 24 & 5.9 & 35 & 8.6 & 350 & 85.5 \\
\hline Using information from various sources & 20 & 4.9 & 87 & 21.3 & 302 & 73.8 \\
\hline
\end{tabular}


To protect themselves from the spread of COVID, most respondents answered that they were reading information about COVID-19, both mode of transmission and prevention $(90.2 \%)$. Over four-fifths of respondents answered that they had made efforts to protect themselves, such as implementing self-protection protocols $(94.4 \%)$, positive thinking (96.1\%), doing activities at home to prevent transmission of COVID-19 $(87.3 \%)$, and trying to limit contact and social distancing (93.2\%) (See Table 4).

The behavior of the community to avoid fake news about COVID-19 is varied. More than half of respondents answered "no" to stop reading news on social media (79.4\%) and just accept the news got from social media $(64.5 \%)$. There are $72.6 \%$ of respondents who ask about news sources to avoid fake news. Most of the respondents considered using news from the government or WHO (85.5\%) and using information from various sources $(73.8 \%)$.

\section{DISCUSSION}

This study revealed that the community of Kendari City has a good knowledge about COVID-19, both regarding transmission and prevention. These results are almost the same as those found in several regions in Indonesia (Yanti et al., 2020) and in several countries such as China (Wang et al., 2020) and United States (Clements, 2020). Knowledge will raise awareness to behave in accordance with his knowledge. The higher knowledge, the greater desire to implement the knowledge (Notoatmodjo, 2012).

This study found that attitudes of community towards opinions about COVID-19 were varied. There were many opinions about COVID-19 which make doubt in the community. A good knowledge can perform positive attitudes. Knowledge and education level are related to the desire to access and receive information (Budiman, 2013; Saimin \& Wicaksono, 2018). Information can affect knowledge, opinions and beliefs in society. Along with technological developments, the public can get information from various sources, including mass media, social media, books, or counselling sheet (Budiman, 2013)

Knowledge and attitudes can influence behavior. Behavior will last longer if we base it on knowledge (Notoatmodjo, 2012). Good community behaviors are essential for an implementing of policies during pandemic. This study found that the people had made efforts to protect themselves from the spread of COVID were adequate. They were reading information about COVID-19, implementing self-protection protocols, positive thinking, doing activities at home to prevent transmission of COVID-19, and trying to limit contact and social distancing. Selfprotecting with using a mask, washing hands and maintaining distance are preventive measures (Kementerian Kesehatan Republik Indonesia, 2020; Visagie, 2020; World Health Organization, $\underline{2020 \mathrm{~b}}$.

During this pandemic, the media has a very important role in providing information to the public. Mass media and social media are easily accessible to the public. However, the information is sometimes inaccurate and incomplete (Shu, Sliva, Wang, Tang, \& Liu; Tasnim, Hossain, \& Mazumder, 2020). The study found that the public has made efforts to avoid fake news about COVID-19. They don't stop reading news on social media, but ask sources. They consider using news from the government or WHO and using information from multiple sources. Therefore, the Government as the policyholder must provide information and direction so that there is no misperception in society.

This study found that there were still respondents who answered "no" and "sometimes" about a behavior. This community must receive attention and education to change their behavior. Knowledge of COVID-19 can influence attitudes and behavior towards implementing new normal policies during the COVID-19 pandemic. Actual evidence of positive behavior is very useful for increasing public knowledge and understanding of COVID-19, so it can reduce negative perceptions and attitudes. To increase knowledge, change negative attitudes and improve behavior, continuing education is needed (Olum, 
Chekwech, Wekha, Nassozi, \& Bongomin, 2020).

\section{CONCLUSION}

Based on this results study, we can conclude it that the people of Kendari City have good knowledge, attitudes and behaviors about COVID-19. This condition is a potential asset to implementing the new normal policy during the COVID-19 pandemic. Continuous information and education are needed to increase knowledge and compliance, change negative attitudes and improve behavior.

Declaration of Conflicting Interest

There is no conflict of interest in this study.

Funding

Self-funded.

References

Budiman, R. A. (2013). Kapita selekta kuesioner: Pengetahuan dan sikap dalam penelitian kesehatan. Jakarta: Salemba Medika, P4-8.

Clements, J. M. (2020). Knowledge and behaviors toward COVID-19 among US residents during the early days of the pandemic: Cross-sectional online questionnaire. JMIR Public Health and Surveillance, 6(2), e19161.

Kementerian Kesehatan Republik Indonesia. (2020). Pengendalian Coronavirus Disease (Covid19). Dirjen Pencegahan dan Pengendalian Penyakit (P2P). Kementrian Kesehatan Republik Indonesia.

Notoatmodjo, S. (2012). Promosi kesehatan dan perilaku kesehatan. Jakarta: Rineka Cipta.

Olum, R., Chekwech, G., Wekha, G., Nassozi, D. R., \& Bongomin, F. (2020). Coronavirus Disease-2019: Knowledge, attitude, and practices of health care workers at makerere university teaching hospitals, Uganda. Frontiers in Public Health, 8, 181.

Pratama. (2020). Menyikapi "new normal" setelah pandemic. [cited: 2020 Agt 31]. Available from: http://puspensos.kemsos.go.id/menyikapi-newnormal-setelah-pandemi

Saimin, J., \& Wicaksono, S. (2018). Cervical cancer screening coverage in urban and rural areas in Southeast Sulawesi: its determinants. Journal of the
Medical Sciences (Berkala ilmu Kedokteran), 50(3), 18.

Shu, K., Sliva, A., Wang, S., Tang, J., \& Liu, H. (2017). Fake news detection on social media: A data mining perspective. ACM SIGKDD Explorations Newsletter, 19(1), 22-36.

Tasnim, S., Hossain, M. M., \& Mazumder, H. (2020). Impact of rumors and misinformation on COVID-19 in social media. Journal of Preventive Medicine and Public Health, 53(3), 171-174.

Visagie, N. (2020). Mitigating the psychological and mental health impact on frontline workers during COVID-19. Belitung Nursing Journal, 6(4), 141-142.

Wang, C., Pan, R., Wan, X., Tan, Y., Xu, L., Ho, C. S., \& Ho, R. C. (2020). Immediate psychological responses and associated factors during the initial stage of the 2019 coronavirus disease (COVID-19) epidemic among the general population in China. International Journal of Environmental Research and Public Health, 17(5), 1729.

World Health Organization. (2020a). WHO TimelineCOVID-19 [cited April 3, 2020]. Available from: https:/www.who.int/news-room/detail/27-04-2020who-timeline---covid-19

World Health Organization. (2020b). Critical preparedness, readiness and response actions for COVID-19. Interim guidance [cited April 3, 2020]. Available from: https://www.who.int/publications-detail/criticalpreparedness-readiness-and-response-actions-forcovid-19

Yanti, B., Wahyudi, E., Wahiduddin, W., Novika, R. G. H., Arina, Y. M. D. a., Martani, N. S., \& Nawan, N. (2020). Community knowledge, attitudes, and behavior towards social distancing policy as prevention transmission of COVID-19 in indonesia. Jurnal Administrasi Kesehatan Indonesia, 8(2), 4-14.

Zhong, B.-L., Luo, W., Li, H.-M., Zhang, Q.-Q., Liu, X.-G., Li, W.-T., \& Li, Y. (2020). Knowledge, attitudes, and practices towards COVID-19 among Chinese residents during the rapid rise period of the COVID-19 outbreak: A quick online cross-sectional survey. International Journal of BiologicalSsciences, 16(10), 1745.

Cite this article as: Saimin, J., Purnamasari, N.I., \& Hartati. (2020). The implementation of new normal policies during the COVID-19 pandemic in Kendari City, Southeast Sulawesi, Indonesia: Knowledge, attitudes and practice. Public Health of Indonesia, 6(3), 99-103. https://dx.doi.org/10.36685/phi.v6i3.346 